\title{
CONSERVATING THE TRADITIONAL CELLARS OF SALACEA, BIHOR COUNTY, ROMANIA
}

\author{
Andreea LINCU * \\ University of Oradea, Faculty of Geography, Tourism and Sport, 1st University Street, \\ Oradea, 410 087, Romania, e-mail: lincu_andreea@yahoo.com

\section{Marin ILIES} \\ University, Sighetu Marmatiei Extension, Faculty of Geography, "Babes-Bolyai" \\ 6 Avram Iancu Street, Sighetu Marmatiei, 437 500, Romania, e-mail: marin_ilies@yahoo.com
}

\section{Dorina Camelia ILIEȘ}

University of Oradea, Department of Geography, Tourism and Territorial Planning, 1 University st., 410087 Oradea, Bihor, Romania, e-mail: iliesdorina@yahoo.com

\section{Grigore Vasile HERMAN}

University of Oradea, Department of Geography, Tourism and Territorial Planning, 1 University st., 410087, Oradea, Romania, e-mail: grigoreherman@yahoo.com

\section{Ștefan BAIAS}

University of Oradea, Department of Geography, Tourism and Territorial Planning, 1 University st., 410087 Oradea, Bihor, Romania, e-mail: baias_stefan@yahoo.com

\section{Maria GOZNER}

University of Oradea, Department of Geography, Tourism and Territorial Planning, 1 University st., 410087, Oradea, Romania, e-mail: mariagozner@yahoo.com

\section{Monica COSTEA}

University of Oradea, Faculty of Environmental Protection, b-dul. Gen. Magheru, nr. 26, Oradea, România, Romania, e-mail: costea.monica@yahoo.it

\section{Dana MIHINCĂU}

University of Oradea, Department of Geography, Tourism and Territorial Planning, 1 University st., 410087, Oradea, Romania, e-mail: danamihincau@gmail.com

Citation: Lincu, A., Ilieş, M., Ilieș, D.C., Herman, G.V., Baias, S., Gozner, M., Costea, M., \& Mihincău, D. (2018). CONSERVATING THE TRADITIONAL CELLARS OF SALACEA, BIHOR COUNTY, ROMANIA. GeoJournal of Tourism and Geosites, 23(3), 748-758. https://doi.org/10.30892/gtg.23311-325

Abstract: This paper argues for the enhanced utilization of the built heritage in the case of the unique cellars of Salacea, Bihor Country which is called „the village of 1000 cellars,.. The research analysis of the cellars includes field investigations, study of existing bibliography, air-photo interpretation. For examining the

\footnotetext{
* Corresponding author
} 
architectureal plans, facades and volumes use was made of software such as: Archicad 22 R1 INT version 22.0.0.3006, Artlantis (2017) 6.5 version 6.5.2.14, Adobe Illustrator CC (2017) version 21.1.0 and Adobe Photoshop CC (2015) version 16.1, and for processing the photos Adobe Lightroom version 6.12. Cartographic materials have been processed in 3D Studio Max, Corel Draw and Corel Photopaint. The use of spatial data allowed identification and analysis of important aspect for understanding the territorial reality. The study identifies two authentic models of cellars that could be exploited for their heritage potential for tourism development and a source of income for the local area.

Key words: cellars, cultural landscape, heritage monuments, Salacea, Romania

\section{INTRODUCTION}

Sălacea commune is located in the north-western part of Romania in the northern extremity of Bihor County, between the Ierului Plain and Sălacei Hills (Figure 1). The altitude of the landscape varies between 100 and $160 \mathrm{~m}$. The areas landscape evolution is the result of climatic-tectonic oscillations and the uninterrupted action of the Ier River and its tributaries (Posea, 1997). The climate is moderate temperatecontinental plain, with Panonic tones, western and northern influences. This, in turn, is reflected directly in the soil types and crops that are suitable for agricultural purposes. Viticulture has been a long established tradition in this area and the traces of this occupation are manifest in the cultural landscape in the physical form of the cellars.

Several previous works refer generally to the cultural landscapes (VÁTI KHT Budapest Compilation, 2000; Ilieș et al., 2014, 2015, 2016, 2017, 2018; Gozner, 2010), with special regard to the landscape in Transylvania (Benedek, 1996); photographic work Sofalvi, 2004) and monographic works (Kéri \& Kántor, 2009; Iren, 2003); Other research address opportunities for touristic capitalization of the oenological and gastronomic tradition (Hava, 2015; Gozner et al., 2016, Gozner \& Avram, 2010). Of note also is a biodiversity study in Salacea wetland (Interreg project, pre-feasibility study, 2017), albeit with no emphasis on Salacea cellars.General works exist referring to the cellars on the hills of Oradea (Dincă et al., 2012; Linc et al., 2017; Tatar et al., 2017). It is the aim in this paper to analyse the architecture and traditional cellars of Salacea and argue that they potentially represent an opportunity for the enhanced utilization of built heritage in this part of Romania. The following discussion is presented as a description of the Salacea cellars as cultural heritage, the methodology results and discussion of different models of cellars, and conclusions.

\section{THE SALACEA CELLARS}

The origins of the Salacea cellars relate to the long tradition of viticulture which has been practiced for hundreds of years in this area. For the inhabitants of Ierului Valley wine production was not only a source of income but also provided status in the local society. The historical evidence suggests that all quality farmers have a patch of vineyard (Benedek, 1996, 101; Hava, 2015). Most of the cellars are concentrated in Sălacea commune, which is known as the "village of the 1000 cellars". Kéri G. and Kántor A. $(2009,104)$ in their study stated that they found evidence of a total of 956 cellars.

Local residents say, however, that this total is an underestimate as each household would have at least one cellar. As is shown on Figure 2 most of the cellars 
are concentrated in groups or rows, in the urban part of the locality (7 rows). It has been observed that the cellars are "an extension of the household at the border of the villages, the expression of a way of life as a result of their adaptation to the environment and also as an argument in favor of a profession that provided people with a chance to make money" (Chiriac, quoted in Sofalvi, 2004). Figure 3 shows the oldest cellar in the village of Sălacea which dates back to 1807 (Iren, 2003) this is evidenced by the inscriptions on the facades of the cellars.

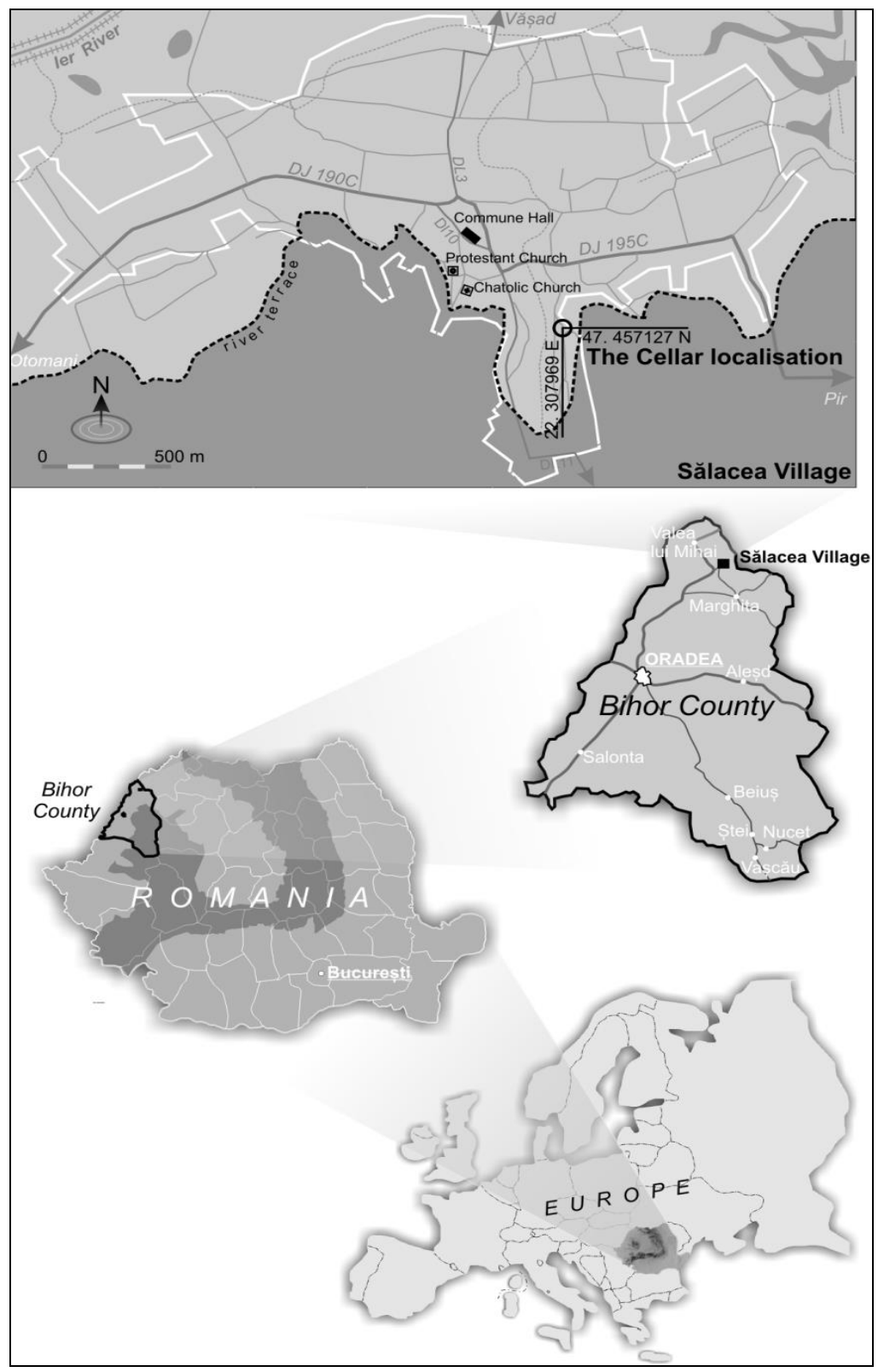

Figure 1. Geographical outline of Salcea, Bihor County, Romania 
Conservating the Traditional

Cellars of Salacea, Bihor County, Romania

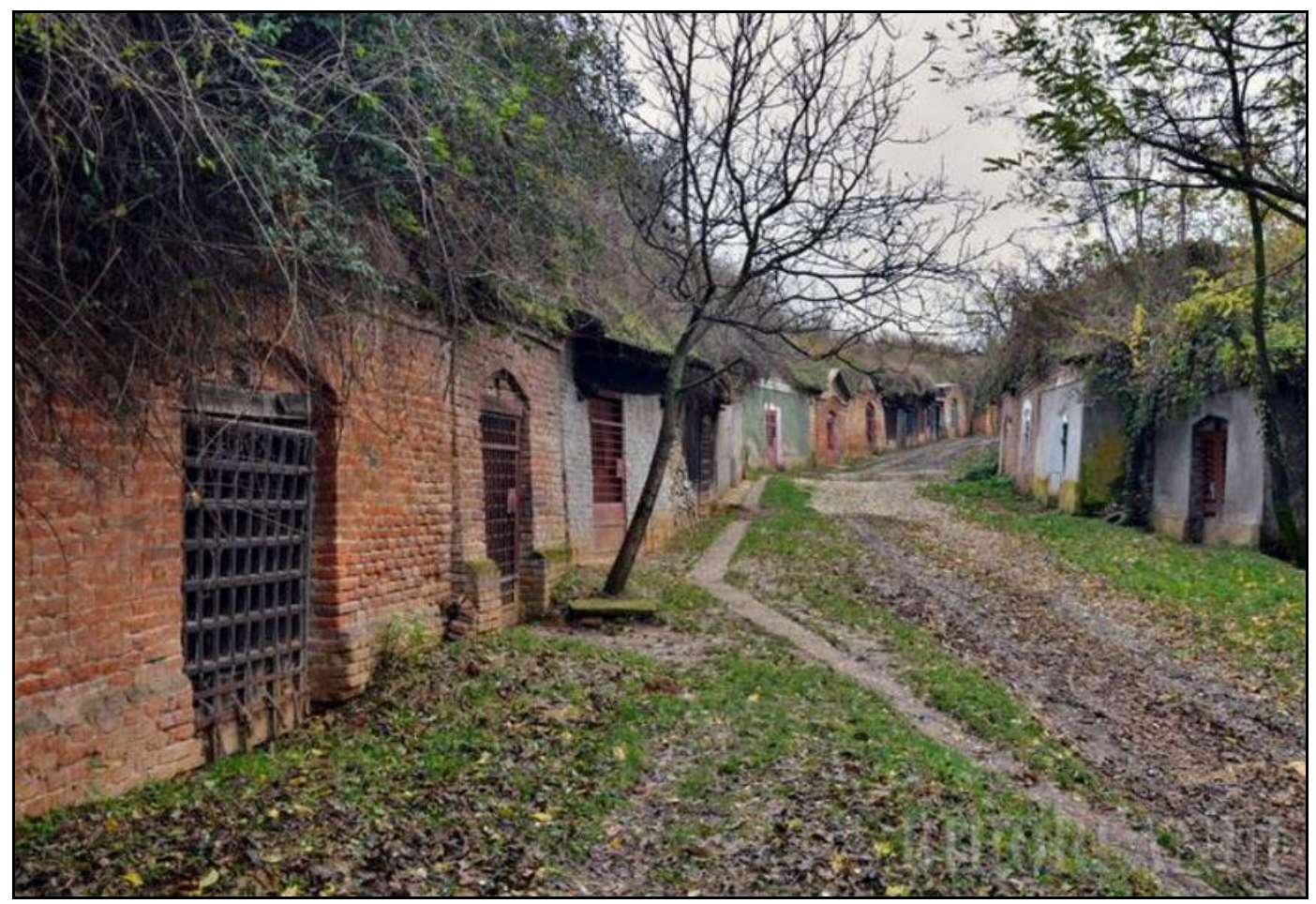

Figure 2. Village street with the row of cellars, Salacea village

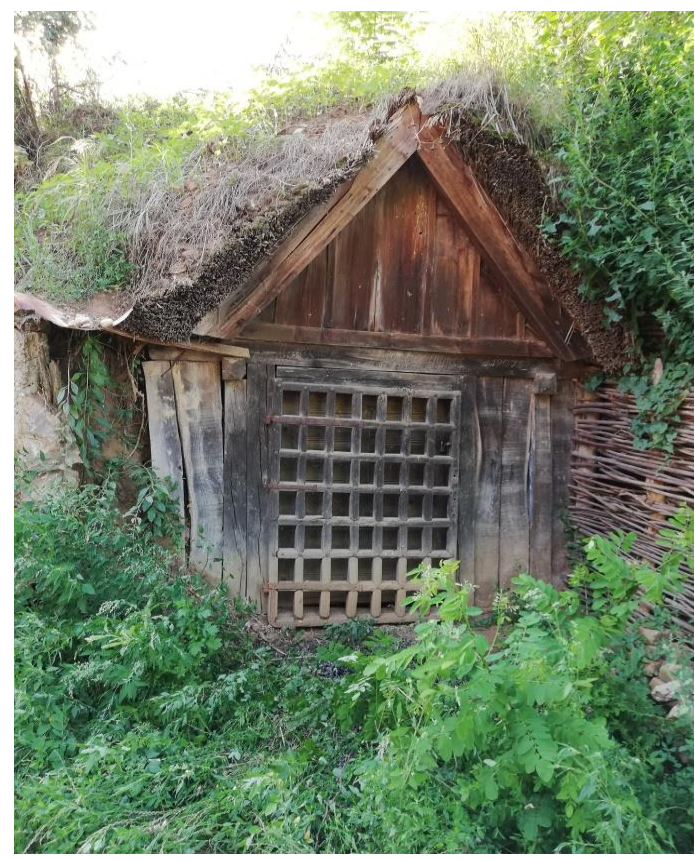

Figure 3. The cellar from 1807, considered to be the oldest on the territory of Salacea village, Bihor county

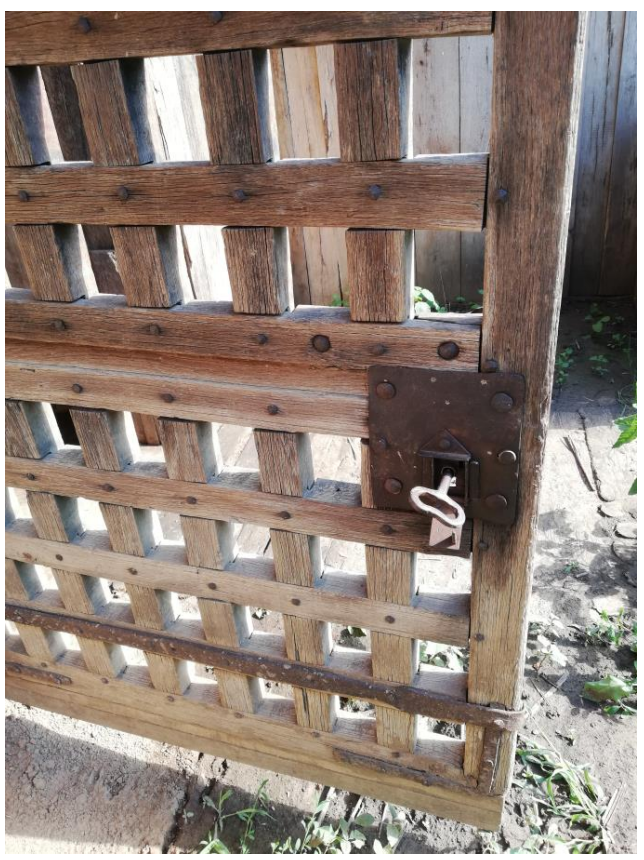

Figure 4. Specific lock to a cellar form Salacea 
Andreea LINCU, Marin ILIEȘ, Dorina Camelia ILIEȘ,

Despite their distinctive architecture and important contribution to the cultural landscape the cellars are not yet listed in the national cultural heritage list (albeit there have been some failed attempts). Figure 4 shows the distinctive architecture of the facades which can be admired, in terms of iron or oak doors, with the specific locks. The importance of the cellars has been described as follows: "they have the role of structuring the space to which they belong, the villagers consider them objects that delineate a space and implicitly its isolation or the preservation of a threshold from the exterior-interior and vice versa, with the meaning that marks a property in the intimacy of which the joys and the difficulties of generations succeed naturally; they are real objects of art, made and promoted by the craftsmen of the past, but also by the passage of time; they are distinguished by sobriety resulting from the use of wood and iron and classical assembly techniques" (Chiriac, quoted in Sofalvi, 2004). Besides the historical and aesthetic values of the monuments, they are important also because they "transmit the knowledge and feelings, develop tastes, educate and learn to appreciate our culture" (Kéri \& Kántor, 2009, 8 and 116).

Overall it has been argued that the cellars play an important role in defining the cultural landscape in this area (Ilieş, 2007). The location and configuration of cellars are the result human adaption to the particularities of the natural environment. As already observed the area is suitable for vineyard growing from a topo-climatic point of view, but it is located on route between Transylvania and Pannonia, contributing to the development of both the production capacities of the wine and that of storage. These cellars are dug into a layer of clay starting from the upper part of the Ier River Terrace. The amount of sand in the clayey layer has determined and limited the dimensions of the excavated galleries. The most common is between $1.25 \mathrm{~m}$ wide and $1.80 \mathrm{~m}$ high with arched ceiling in the shape of a circular arch. Cellar chambers were long due to width and height limitations. The existence of the impermeable clay layer is the proof of resistance to water infiltration and contributes to the inner microclimate. Obtaining a suitable shelter for keeping the wine was also based on the predominantly northern orientation of the river's terrace, and on the fact that the line marking the edge of the terrace has a very sinuous route with a ratio of 1 to 3 . On the thalweg of some perpendicular valleys on the edge of the terrace a few concavities developed, greatly increasing the working area.

The configuration resulted in similar arrangements to inner courtyards, with cellars close to or around or in front of each other. The cellars are dug in the upper part of the river's terrace, between the altitudes of 130-140m, in direct harmony with the horizon corresponding to the clayey layer. In some sectors, the thickness of the clayey horizon and the altitude difference between the valley talweg and the terrace floor allowed a number of cellar rows to be excavated on several levels on altitude. Practically, the cellar dimensions are tailored to the natural features of the area, being probably the result of longer-lived local practices. They have strongly influenced the structure of households, even villages (besides the social life of local people) (Ilies, 2007). The cultural landscape of Salacea (Gavra, 2013) graphically demonstrates the long tradition of wine production in this region of low hills and river valleys. The intricate pattern of vineyards, farms, villages, with their historic networks of deep wine cellars, illustrates every facet of the production of the wines (VÁTI KHT - Budapest Compilation, 2000).

\section{METHODOLOGY}

In terms of methodology a range of approaches were used. A study of existing bibliography, field investigations, and air-photo interpretation was performed. For the understanding of plans, facades and volumes we used software such as: Archicad 22 R1 INT 
Conservating the Traditional

Cellars of Salacea, Bihor County, Romania

version 22.0.0.3006, Artlantis (2017) 6.5 version 6.5.2.14, Adobe Illustrator CC (2017) version 21.1.o and Adobe Photoshop CC (2015) version 16.1. For the processing of photos we used Adobe Lightroom version 6.12. The particularities of the territory were analyzed by the spatial correlation of data stored on the layers, information from topographic and geological maps, orthophotoplans, PUGs (General Urbanistic Plann), publications and field surveys.
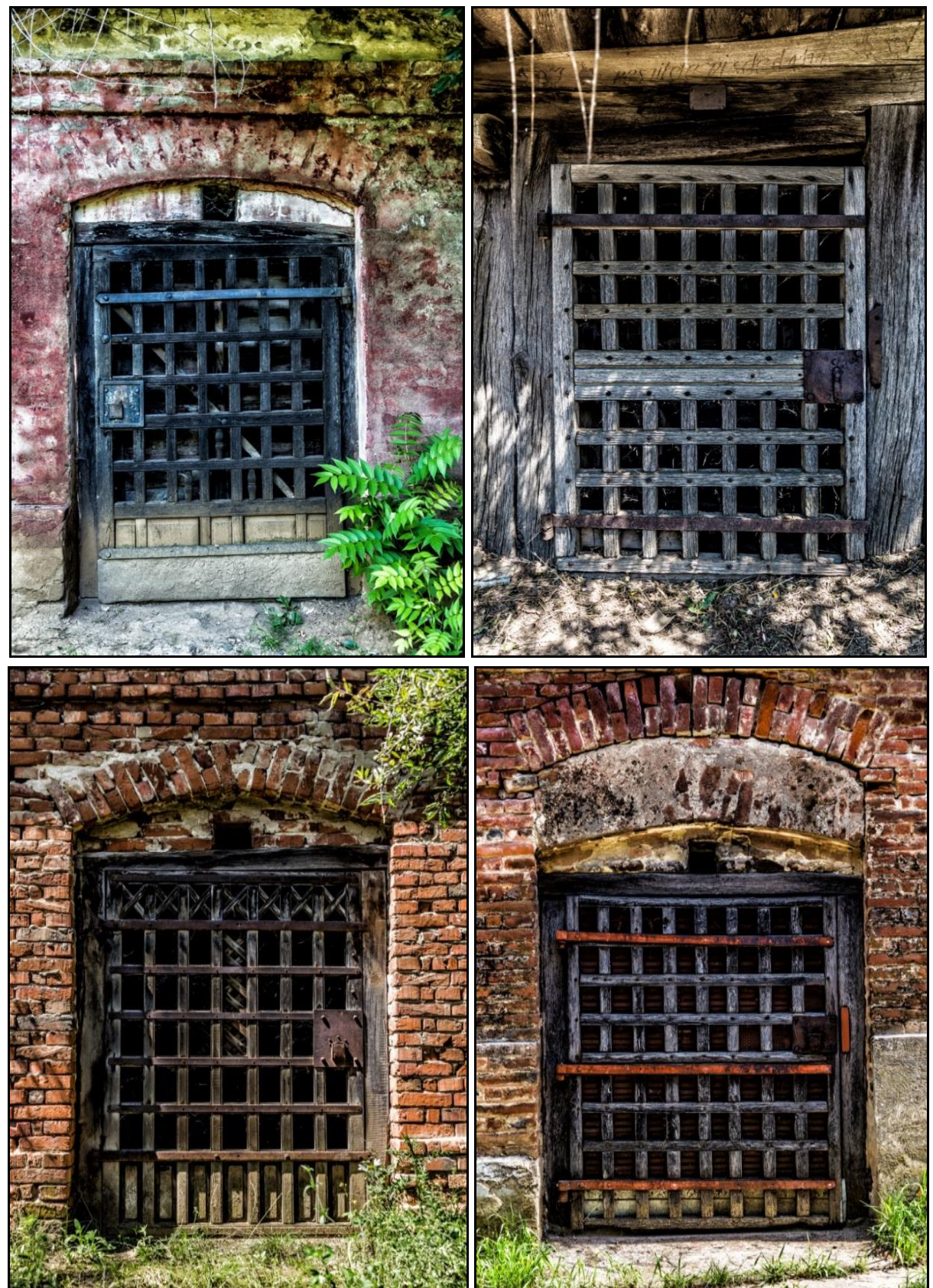

Figure 5. Wooden oak doors reinforced with wrought iron, Salacea cellars, Bihor 
Andreea LINCU, Marin ILIEȘ, Dorina Camelia ILIEȘ,

Grigore Vasile HERMAN, Ștefan BAIAS, Maria GOZNER, Monica COSTEA, Dana MIHINCĂU

Being a low-altitude, slightly waved area, all land details have been used: abandoned meanders, recent river basins, river terraces, land elevations, toponyms, current roads and old roads, and hydrotechnical facilities. Cartographic materials have been processed in $3 \mathrm{D}$ Studio Max, Corel Draw and Corel Photopaint. Spatial data interference has allowed for the identification and analysis of important aspects for understanding this territorial reality.

\section{RESULTS AND DISCUSSION}

Figures 5 to 7 provide an illustration and evidence of the different forms of cellars which occur at Salacea. Using the methodologies as described above Figures 8 to 13 prenent our analysis of the architectural design of the cellars. It is evident that most of the cellars are made of burnt brick, but there are also other types which are made of wood or mud brick with a reed roof. Because the area consists of low-lying fluvial-lake deposits, there are no hard rocks, which is why they do not appear in the cellar construction. All the other materials are found in the local horizon, being more than a differentiation depending on the level of processing, that is, the mud brick or brick, both made of clay. As shown according to Figures 8 to 11 their layout comprises: a hall in which, if the surface permits, the grapes are pressed and the wine is produced. This is followed by the room called by the locals as the "neck", which is the passage to the cellar room where the various goods are stored. Here the most valuable pocessions of the family were stored, namely: food and wine. The mayor of the Salacea commune stated as follows: "The size of cellars represented the measuring unit of family wealth. The bigger the cellar, the more wealthy the family" (B. Horváth, Mayor of Sălacea commune 2018).

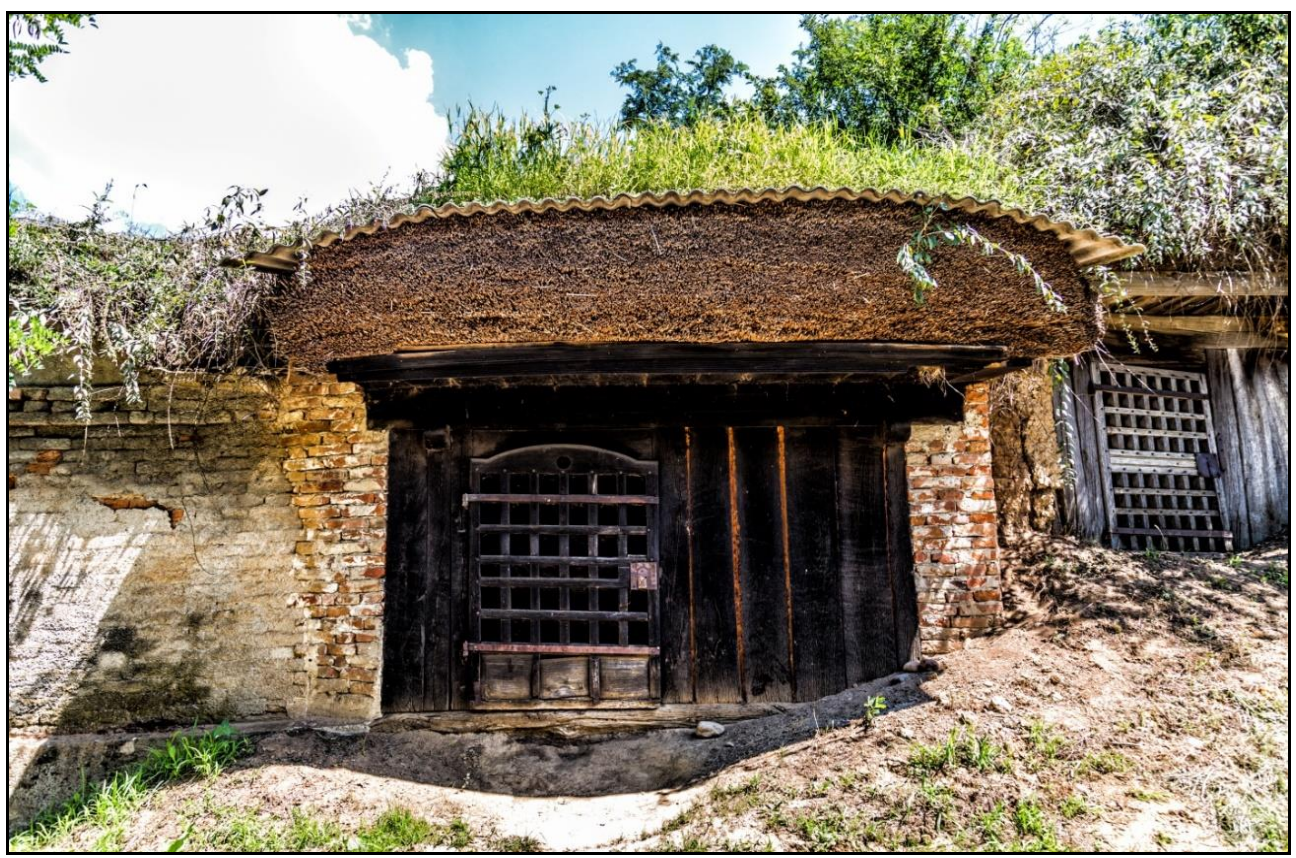

Figure 6. Brick cellar Salacea

Our analysis shows the existence of two distinct cellar models in the area. The first authentic cellar model found in Sălacea commune is built of burnt brick, completely covered with earth, leaving only the façade visible. The brick is apparent, not plastered. 
Conservating the Traditional

Cellars of Salacea, Bihor County, Romania

The façade can be crowned with a gable of different shapes and decorated with different patterns of the brick (Figures 6, 8, 9, 10). The second authentic model of the cellar identified is made of wood, mud brick and reed, and it is also covered entirely with earth.

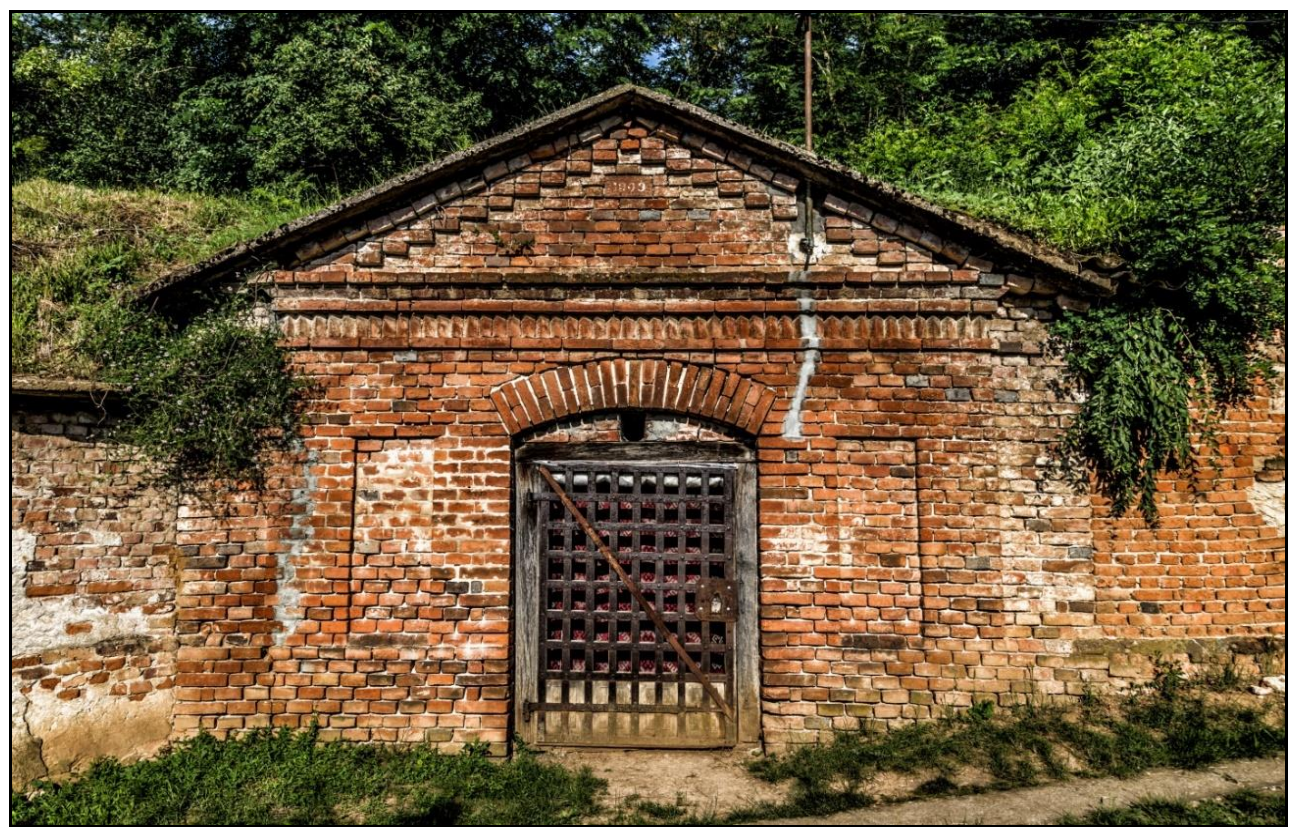

Figure 7. Wooden cellar and reed Salacea

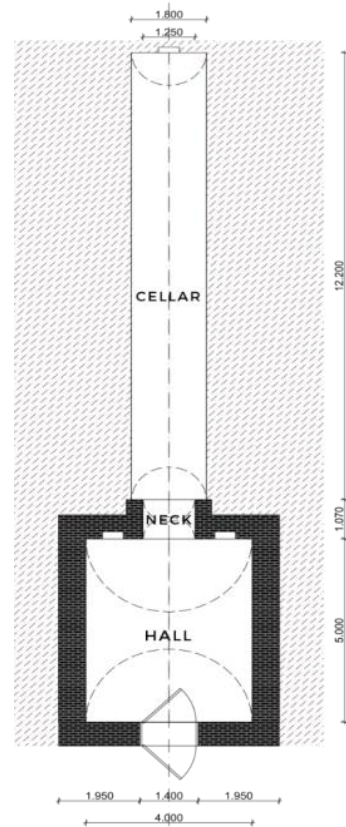

Figure 8. Brick cellar plan, Salacea

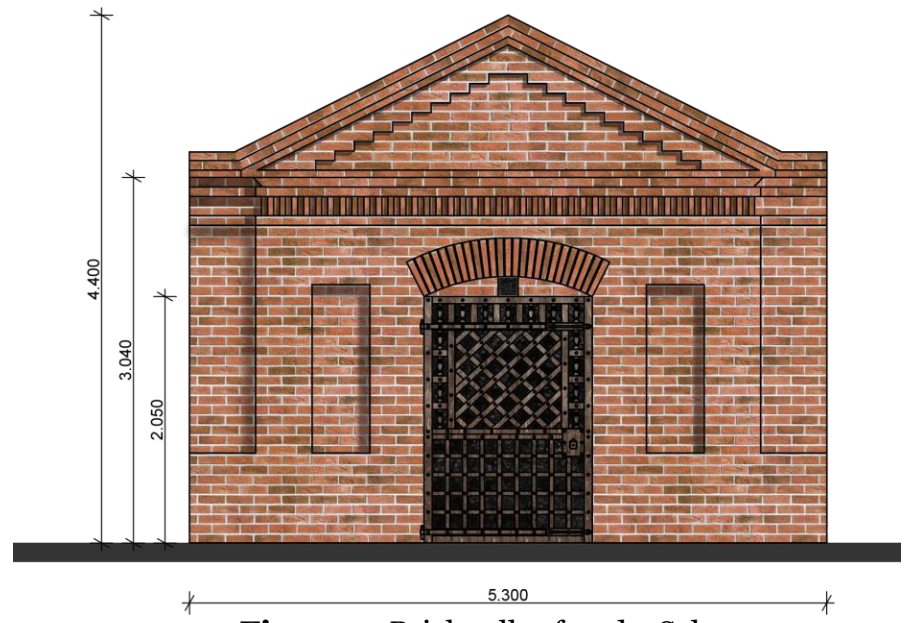

Figure 9. Brick cellar facade, Salacea 
Andreea LINCU, Marin ILIEȘ, Dorina Camelia ILIEȘ, Grigore Vasile HERMAN, Ștefan BAIAS, Maria GOZNER, Monica COSTEA, Dana MIHINCĂU

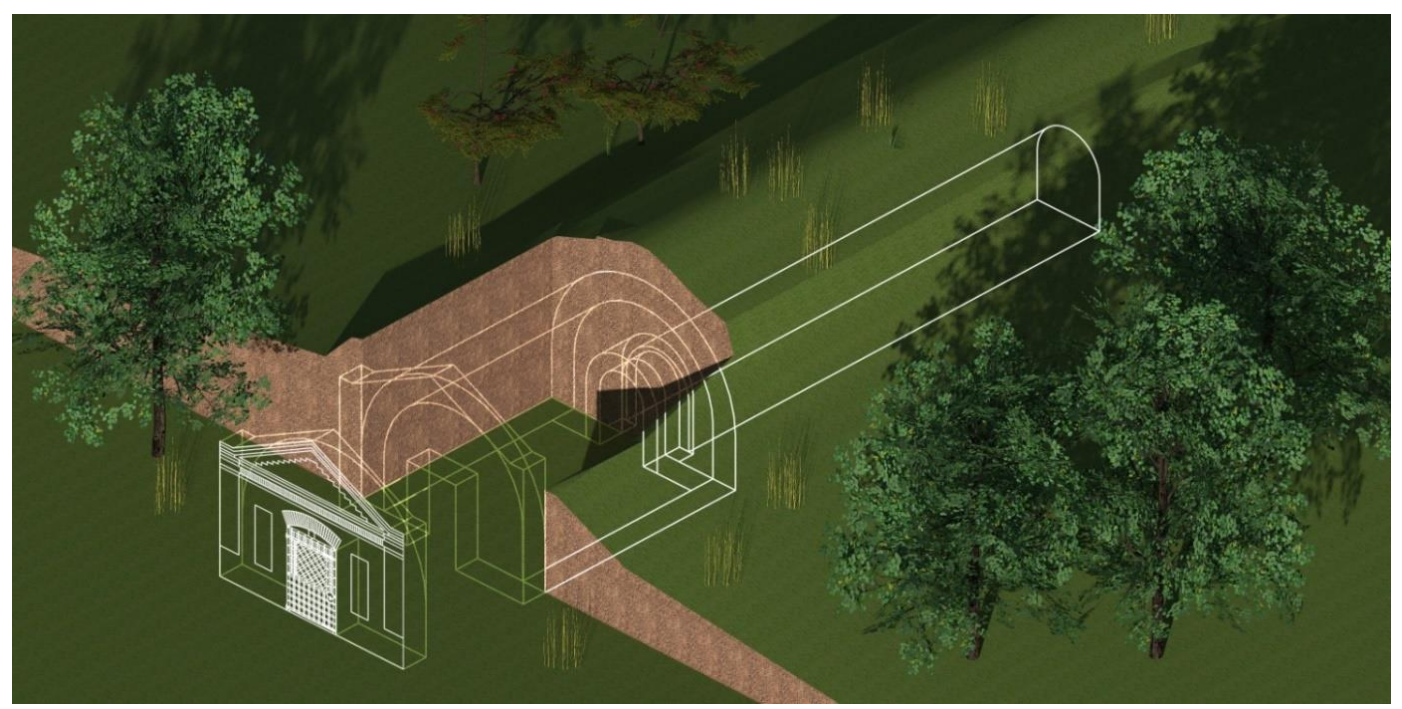

Figure 10. Brick cellar volume, Salacea

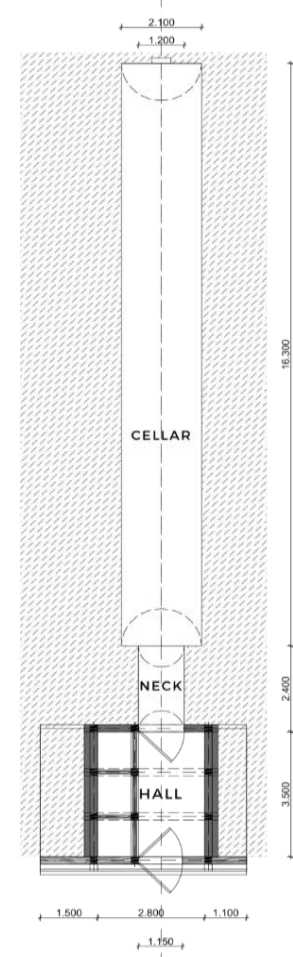

Figure 11. Plan of wooden, mud brick and reed cellar, Salacea

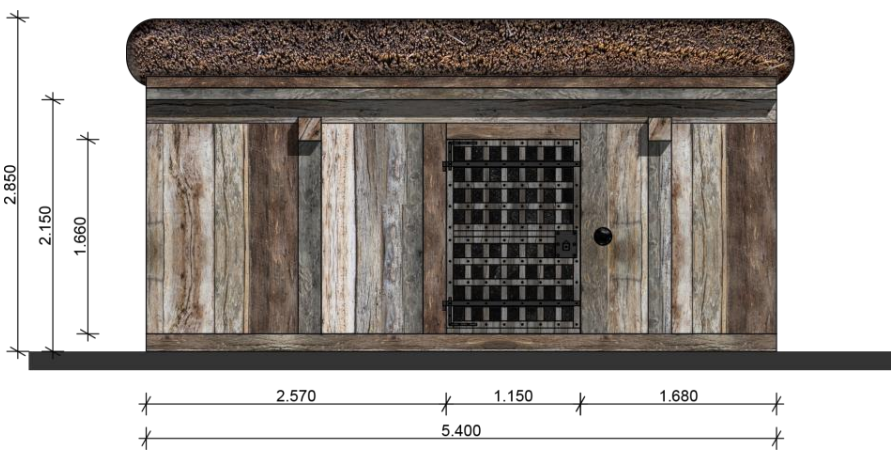

Figure 12. Facade of wooden, mud brick and reed cellar, Salacea

The façade is entirely made of oak wood and is not decorated (Figure 7, 11, 12, 13). In both cases the cellars are dug at a depth of about 2-3 $\mathrm{m}$ deep. Both facades have as 
their main central point the door which is made of oak and wrought iron (Figure 5). They play an important role in creating a unitary set. They are specific to these types of cellars and, together with the special locks, they create an identity. The locks open through various secret combinations by means of oversized keys.

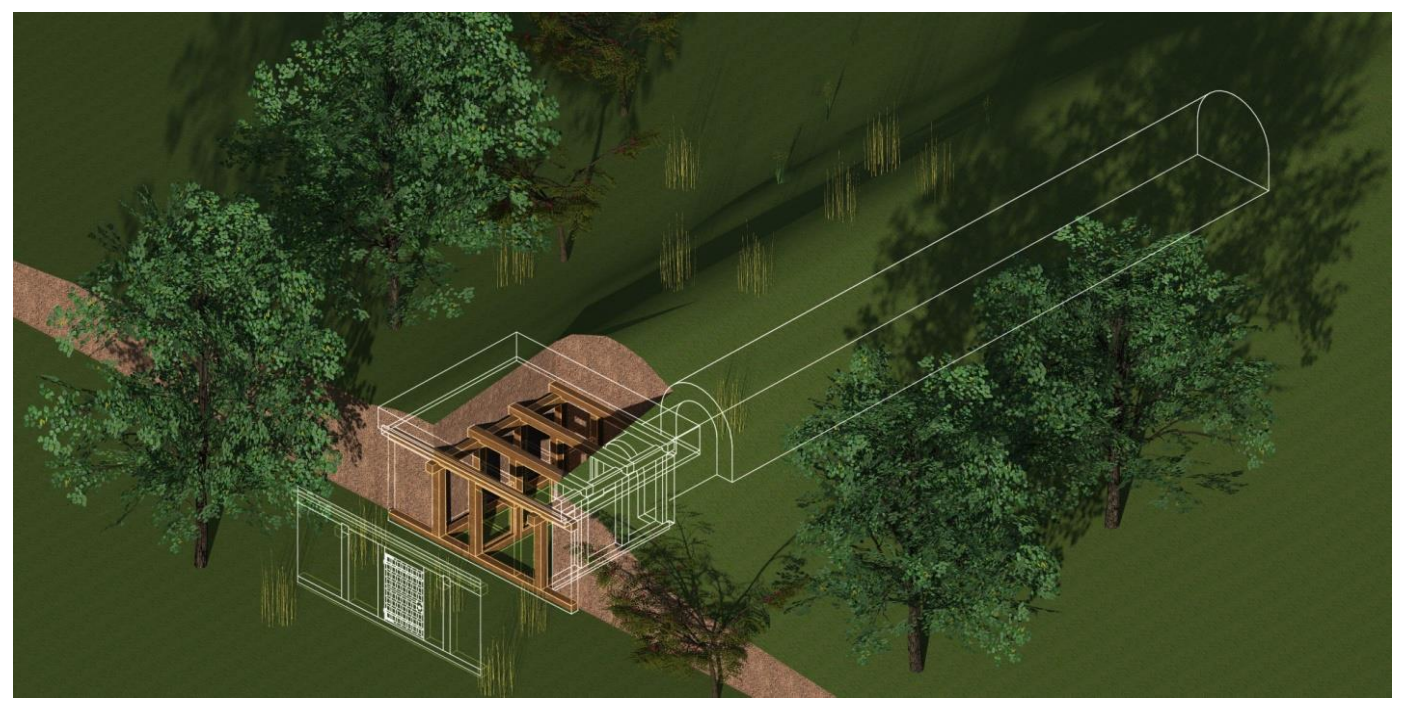

Figure 13. Volumetric analysis of wooden, mud brick cellar, Salacea

\section{CONCLUSIONS}

The analysis which is undertaken here of traditional wine cellars of Celcea Romania, highlights their importance in the traditional cultural landscape and their potential as heritage resources which might be maximized for the benefit of the local community. It has been argued that these cellar ensembles are living testimonies of traditions and habits about historical viticulture. They have a specific character and are remarkable as heritage values. It is noted that the cellars are not included in the List of Historical Monuments of Romania. From our analysis we consider that the cellars have historical-architectural value, and that their great density, the special personality justifies their recognition as important local monuments which can be of interest for local tourism as well as regional and international visitors. In terms of territorial planners the identification of different types of authentic cellars identified can support local authoritis planning in particular in terms of restoring and rebuilding some of the cellars which are at risk of falling into disrepair.

\section{Acknowledgement}

The monitoring and sampling are not invasive. The authors wish to acknowledge the support of the grant PN-III-P1-1.2-PCCDI-2017-0686.

\section{REFERENCES}

Benedek, Z. (1996). Érmellék - Erdélyi tájak / Ierului Valley Landscape from Ardeal Editura Helios, Orosháza, Hungary, p. 101.

Dincă, I., Herman, G. V., \& Sztankovics, G. (2012). Descoperire prin ecoturism şi prin turism rural comuna Cetariu/Discovery through ecotourism and rural tourism of Cetariu commune. Ed. Universităţii din Oradea. 
Andreea LINCU, Marin ILIEȘ, Dorina Camelia ILIEȘ,

Gavra, C.I. (2013). Peisaje culturale in Muntii Metaliferi / Cultural landcape from Apuseni Mountains, Risoprint, Cluj Napoca, $271 \mathrm{p}$.

Gozner, M., \& Avram, M. (2010), The situation of the natural reservation from the Territorial System Albac - Arieseni. Analele Universităţii din Oradea, Seria Geografie, Tom XX, Editura Universităţii din Oradea;

Gozner, M. (2010) Tourism in the Territorial System Albac - Arieseni sistemul teritorial Albac and its impact on the environment. Analele Universităţii din Oradea, Fascicula Construcţii şi Instalaţii Hidroedilitare, vol. XIII - 2, Editura Universităţii din Oradea

Gozner, M., Josan, I., Baias, S., \& Măduta, F.M., (2016), The Religious Attractions - An Expression of Authenticity in the Territorial System Albac - Arieşeni and Alba County (Romania). GeoJournal of Tourism and Geosites, Year VIII, Volume 15, Oradea-Gdansk, Romania-Poland, Ed. Universității din Oradea.

Hava, F. G. (2015). Pivnițele independente de gospodării din Satul Sălacea-valorificarea turistică a tradiției oenologice şi gastronomice locale/ The household independent cellars from Sălacea Village-tourist valorisation-oenology and local gastronomy. Lucrare de licenta,Universitatea din Oradea, $271 \mathrm{p}$.

Ilies A. (Coord.), Baias S, Baias Iuliana, Blaga L., Buhaș S., Chiriac A., Ciocan Janeta, Dăncuș M., Deac Anca, Dragoș P., Dumitrescu G., Gaceu O., Godea I., Gozner Maria, Grama V., Herman G., Hodor N., Hurley P., Ilieș Dorina, Ilieș Gabriela, Ilieș M., Josan Ioana, Leșe G., Măduța F., Mojolic Diana, Morar C., Olaru M., Stașac M., Stupariu M., Sturza Amalia, Ștefănescu B., Tătar Corina, Vârnav R., Vlaicu M., \& Wendt J., (2014). Crisana-Maramures. Atlas geografic al patrimoniului turistic/ Geographical atlas of tourism heritage, 302 pp., Editura Universității din Oradea, ISBN 978-606-10-1298-5.

Ilieş, A., Wendt, J.A., (2015). Tourism geography. The basic of theory and application issues. [Geografia turystyczna. Podstawy teorii i zagadnienia aplikacyjne]. Wydawnictwo AWFiS, Gdańsk.

Ilieș, A., Hurley P. D., Ilies D. C., \& Baias Ș. (2017). Tourist animation - a chance adding value to traditional heritage: case studys in the Land of Maramures (Romania). Revista de etnografie şifolclor, New Series 1-2.

Ilieş, A., Wendt, J., Ilieş, D. C., Herman, G. V., Ilieş M., \& Deac A. L. (2016). The Patrimony of Wooden Churches, Built Between 1531 and 2015, in the Land of Maramureș, Romania. Journal of Maps, Volume 12, pp 597-602.

Ilieș, D. C., Onet, A., Wendt, J., Ilieș, M., Timar, A., Ilieș, A., Baias S., \& Herman, G. V. (2018). Study on microbial and fungal contamination of air and wooden surfaces inside of a istorical Church from Romania. Journal of Environmental Biology, vol 39/6, 980-984.

Ilieș, D. C., Buhaș, R., Ilieș, A., Gaceu, O., Oneț, A., Buhaș, S., Rahotă, D., Dragoș, P., Baias, Ș., Marcu, F, \& Oneț, C. (2018). Indoor air quality issues. Case study: the multipurpose sport hall of the University of Oradea. Environmental Engineering and Management Journal, (http://www.eemj.icpm. tuiasi.ro/pdfs/ accepted/213_544_Ilies_17.pdf).

Ilieș, M. (2007). Amenajare turistică/Tourist planning. Editura Casa Cărții de Știință, Cluj-Napoca.

Iren, G. (2003). Szalacs Kismonografia. Partium Fuzatek. 26.

Kéri, G., \& Kántor, A. (2009). Az érmelleki szőlőmüvelés épitészeti és tárgyi emlékeinek védelme. Hajdúböszörmény, p. 118.

Linc, R., Dincă, I., Tătar, C., Staşac, M., Nistor, S., \& Bucur, L. (2017). The household independent cellars of Oradea Hills, Romania: a chance to continuity through the human and environmental capital. Analele Universităţii din Oradea, Seria Geografie 27 (2): 141-152.

Posea, G. (1997). Câmpia de Vest a României, Editura Fundaţiei „România de Mâine”, Bucureşti.

Sofalvi, S. (2004). Pivnite de vinuri din Valea Ierului. Expoziție fotografică.

Tătar C., Dincă I., Linc R., Nistor S., Judea D., Bucur L., \& Stașac M. (2017). Rural Landscape Regeneration by the Household Independent Cellars' Geospatial Analysis and Rehabilitation, în vol. Conf. Modern Technologies for the 3 rd Millennium, EDlearning, published by Thomson Reuters - Philadelphia formerly Institute for Scientific Information ISI, EDITOGRAFICA s.r.l., Bologna (Italy), ISBN 978-8887729-41-2, http://www.edlearning.it p. 89-98.

*** VÁTI KHT - Budapest Compilation (2000). Tokaj Wine Region Historic Cultural Landscape, THE WORLD HERITAGE Documentation for the nomination of the CULTURAL LANDSCAPE OFTOKAJI WINE REGION REPUBLIC OF HUNGARY, Present study is based on various contributions Compiled byVÁTI KHT - Budapest, commissioned by the Hungarian Ministry of Environment Protection, Authority for Nature Conservation Budapest 2000, $51 \mathrm{p}$.

*** Studiu de fezabilitate/Fesability study. Extinderea zonei mlastinoase din Salacea si valorificarea parcului Komaromi din Otomani/Extension of wet land from Salacea and valorisation of Komaromi Park, from Otomani, 2017, Programul Interreg Romania-Ungaria/Interreg Programme Romania-Hungary „from one bridge to another Hidtol-Hidig”, 440 p, Arhipelag Design.

Submitted:

03.08.2018
Revised:

29.10.2018
Accepted and published online 01.11.2018 